\title{
Enhanced Indirect Organogenesis and Efficient Shoot Multiplication of Petunia hybrida
}

\author{
Azza A. Tawfik, O.H.M. Ibrahim and Mona A.A. Taha \\ Ornamental Plants and Landscape Gardening Department, Faculty of Agriculture, \\ Assiut University, 71526, Egypt.
}

\begin{abstract}
STUDY was initiated through various experiments aiming to optimize different $A$ stages including callus induction, shoot regeneration, shoot multiplication, rooting and acclimatization of Petunia hybrida. Callogenesis from leaves of in vitro-grown seedling was observed on MS medium supplemented with $0.1 \mathrm{mg} / 1$ NAA combined with BAP at various concentrations $(0.0,0.25,0.5$ and $1.0 \mathrm{mg} / \mathrm{l})$. The results indicated that the medium with BAP at $0.5 \mathrm{mg} / \mathrm{l}$ in combination with NAA at $0.1 \mathrm{mg} / \mathrm{l}$ resulted in the highest percentage for explants producing callus $(40 \%)$. Callus was transferred to regeneration medium to study the effect of three types of cytokinins including BAP, TDZ and Kin at different concentrations $(0.0,0.2$, $0.4,0.6,0.8$ and $1.0 \mathrm{mg} / 1$ ). The results showed that BAP at $0.2 \mathrm{mg} / 1$ or $\mathrm{TDZ}$ at 0.2 or 0.4 $\mathrm{mg} / \mathrm{l}$ induced the highest multiplication capacity (90\%). Another experiment employed four MS basal salt strengths (full, $3 / 4,1 / 2$ and $1 / 4$ MS) in combination with three concentrations of sucrose (20, 30 and $40 \mathrm{~g} / \mathrm{l})$. Full strength MS basal salt medium with sucrose (40 g/l) boosted multiplication performance. Multiplied shoots were studied for rooting ability. Applying sucrose at the lowest concentration $(15 \mathrm{~g} / \mathrm{l})$ with full or $1 / 2 \mathrm{MS}$ produced the highest rooting percent $(100 \%)$, the highest number of roots $(8.33)$ per shoot and the longest roots $(12.03 \mathrm{~cm})$. The well rooted plantlets were successfully acclimatized on different potting media including peat moss, vermiculite, clay and perlite where clay surpassed other growing medium mixtures with a $89 \%$ survival rate.
\end{abstract}

Keywords: Adventitious shoots, Callus, Cytokinins, Hyperhydricity (vetrification), MS salt strength medium, Subculture, Sucrose,

Abbreviations: $\mathrm{MS}=$ Murashige and Skoog medium, NAA=1-Naphthaleneacetic acid, BAP=6Benzylaminopurine, Kin=Kinetin ( $\mathrm{N}^{6}$-furfuryladenine), TDZ=Thidiazuron

\section{Introduction}

Petunia x hybrida (Hook.) Vilm. (P. hybrida) known as the common garden petunia belongs to family Solanaceae and it is endemic to temperate and subtropical regions of South America. It comprises annual or perennial herbs derived from $P$. integrifolia and $P$. axillaris. The garden petunia was first obtained by hybridization in 1834 by Atkins of Northampton, a British nurseryman, and it soon spread to European gardens (Stehmann et al., 2009). It is among the most famous and commercially important bedding plants. Importance of petunia has been beyond being just an excellent bedding plant since it has played a key role in genetic transformation contributing to elucidating many of the characteristics of plant transformation research which dates back to the earliest reports of this subject (Conner et al., 2009 and Deroles et al., 1996).

An efficient protocol for in vitro regeneration of Petunia hybrida is a prerequisite for applying plant improvement programs. The same tissue culture protocol is not applicable to different genotypes due to the poor performance exhibited by some genotypes for growth and development in tissue culture comparing to the high aptitude of others (Conner et al., 2009). Different species of petunia have been investigated in order to optimize an in vitro regeneration protocol suitable for each species (George et al., 2008 and Jamshidnia \& BE 2013). Several explant types have been reported including protoplast, cotyledon and leaf explants

Corresponding author: Omer.H.M Ibrahim, e.mail: omer_hooo@yahoo.com

DOI: 10.21608/ejoh.2018.6058.1084

C2019 National Information and Documentation Centre (NIDOC) 
(Fan etal., 2009, Jin et al, 2007, Kag et al., 2018, and Meyer et al., 2009). The optimal levels of growth regulators and various culture conditions strongly vary according to the requirements of different genotypes (George et al., 2008 and Skvirsky et al., 1984). Some of these culture conditions have been addressed in previous investigations on petunia including sugar (Raquin, 1983 and Zimmerman \& Cobb, 1989), and plant growth regulators (AbuQaoud, 2012 and Thirukkumaran et al., 2009). Different types of cytokinins with a wide range of concentration have been reported as optimal for shoot regeneration from leaf explants of petunia. These include BAP from 0.1 to $2 \mathrm{mg} / \mathrm{l}$ (Fan et al., 2009, and Kag et al., 2018), TDZ (Thirukkumaran et al., 2009). Kinetin and $\alpha$-naphthalene acetic acid (NAA) has been reported as well for callus induction stage (Abu-Qaoud, 2012).

Other important factors which affect the regeneration in vitro are the strength of basal salt MS medium and subculture cycles. These two factors haven't been reported for in vitro regeneration of petunia. Even though, the effect of repeated subcultures has been reported on other plant species such as Gladiolus hybridus (Aftab et al., 2008), Vitex negundo (Rani and Nair, 2006) and Euphorbia tirucalli (Uchida et al., 2004) and the effect of basal salt strength was reported on Zingiber officinalis (Villamor, 2010). However, severe disadvantages may occurred and hinder the tissue culture techniques unless they are well managed. Among these disadvantages, hyperhydricity, previously known as vitrification appears as a consequence of very high humidity in the head space of tissue culture containers causing deterioration of plant growth and subsequently death of tissues (Rojas-Martinez et al., 2010). Aiming to reduce hyperhydricity, several previous investigations have been reported (Gao et al., 2017, Whitehouse et al., 2002 and Zimmerman \& Cobb, 1989).

The current study aims to examine the optimal PGRs type and concentration, the strength of basal salt MS medium, number of subculture cycles and sucrose concentration for callus induction and regeneration, multiplication and subsequent rooting of the regenerated shoots of Petunia hybrida.

\section{Materials and Methods}

\section{Culture conditions}

All experiments in this study were conducted twice during 2017 and 2018 at plant tissue culture Egypt. J. Hort. Vol. 46, No.1 (2019) laboratory, Department of Ornamental Plants and Landscape Gardening, Faculty of Agriculture, Assiut University. Murashige and Skoog (MS) basal medium (Murashige and Skoog, 1962) was used in all the experiments. Unless otherwise stated, the medium was solidified with $7.5 \mathrm{~g}$ agar/1 $(\mathrm{w} / \mathrm{v})$ and the $\mathrm{pH}$ of the medium was adjusted to 5.8 prior to autoclaving at $121^{\circ} \mathrm{C}$ and $1.5 \mathrm{~kg} / \mathrm{cm}^{2}$ for $30 \mathrm{~min}$. The cultures of all experiments were incubated at $25 \pm 2{ }^{\circ} \mathrm{C}$ under 16 hours light from cool white fluorescent tubes.

\section{Callus induction from leaves of in vitro- germinated seeds}

Seeds of Petunia hybrida were collected from the nursery of ornamental plants, Faculty of Agriculture, Assiut University. The seeds were washed under running tap water and surface sterilized under aseptic conditions for five minutes in a $50 \%$ ethanol and then rinsed thrice with sterile distilled water for five minutes each. Surface sterilized seeds were germinated in $250 \mathrm{ml}$ baby-food jars containing $30 \mathrm{ml}$ of MS medium supplemented with $30 \mathrm{~g} / 1$ sucrose (Fig 1 A\&B). For callus induction, whole leaves taken from in vitro-growing seedling were cultured on MS basal medium supplemented with NAA at 0.0 and $0.1 \mathrm{mg} / \mathrm{l}$ combined with BAP at various concentrations $(0.0,0.25,0.5$ and $1.0 \mathrm{mg} / \mathrm{l})$. The leaves were placed with their abaxial surface firmly in contact with the medium (Fig.1 C). The experiment was factorial $(2 \times 4)$ arranged in a randomized complete block design. Data were taken on the percentage of explants forming callus in addition to the visual observations on callus characteristics after 21 days of culture the explant. The induced calluses were subcultured on PGRsfree MS medium for one week to eliminate any residual effect of any PGRs used and then were used for the regeneration experiment.

\section{Adventitious shoot organogenesis from callus explants}

Calluses were divided into $\sim 3-5 \mathrm{~mm}$ diameter pieces and transferred to MS basal medium supplemented with $30 \mathrm{~g} / 1$ sucrose. Three types of cytokinins were investigated including BAP, TDZ and Kin at different concentrations $(0.0,0.2$, $0.4,0.6,0.8$ and $1.0 \mathrm{mg} / \mathrm{l})$. The experiment was designed as $3 \times 6$ factorial experiment with three replicates. Each replicate comprised five jars, each jar containing 4 callus pieces. After 4 weeks, data were recorded on percentage of regenerating explants, percentage of explants forming callus, number of shoots regenerated per callus explants, 
leaf number per shoot and hyperhydricity (vitrification) percentage.

\section{Shoot multiplication \\ Effect of cytokinin type and concentration on shoot multiplication}

Shoot segments ( $\sim-2 \mathrm{~cm}$ with $2-3$ nodes) were prepared from the regenerated shoots in the previous experiment. Two explants were cultured per a $250 \mathrm{ml}$ baby-food jar containing MS basal medium supplemented with $30 \mathrm{~g} / \mathrm{l}$ sucrose. Three types of cytokinins were investigated including BAP, TDZ and Kin at different concentrations $(0.0$, $0.2,0.4,0.6,0.8$ and $1.0 \mathrm{mg} / \mathrm{l})$. The experiment was designed as $3 \times 6$ factorial experiment in a randomized complete block design (RCBD) with three replicates and five jars per replicate. Data were recorded -after 4 weeks- on percentage of explants producing shoots, percentage of explants forming callus, number of shoots per explant, shoot length $(\mathrm{cm})$, number of leaves per shoot and hyperhydricity (vitrification) percentage.

Effect of repeated subculturing and cytokinins on shoot multiplication

Microcuttings ( 1-2 cm with 2-3 nodes) attained from the shoots in the multiplication stage were cultured in $250 \mathrm{ml}$ baby-food jars containing $30 \mathrm{ml}$ MS basal medium supplemented with optimal cytokinin concentration of BAP $(0.2$ $\mathrm{mg} / \mathrm{l})$, TDZ (0.4 mg/l) or Kin $(0.4 \mathrm{mg} / \mathrm{l})$. After 3 weeks, the microcuttings were subcultured on the same fresh medium. Two microcuttings per jar and five jars were used per replicate with a total of three replicates per treatment. The experiment was arranged in a completely randomized design (CRD). The subculture were repeated every threeweek for a total of four cycles of subculturing. Data were recorded after each subculture on percentage of explants producing shoots, percentage of explants forming callus, number of shoots per explant, shoot length $(\mathrm{cm})$, number of leaves per shoot and hyperhydricity percentage.

Effect of basal salt strength and sucrose concentrations on multiplication behavior

Microcuttings ( 1 - $2 \mathrm{~cm}$ with 2-3 nodes) excise from the shoots in the multiplication stage were cultured on MS salt basal media with four different strengths ( full, $3 / 4,1 / 2$ and $1 / 4$ strength) in combination with three concentrations of sucrose $(20,30$ and 40 $\mathrm{g} / \mathrm{l})$. All media were supplemented with a BAP at $0.2 \mathrm{mg} / \mathrm{l}$. The experiment was designed in $4 \times 3$ factorial treatment combinations in randomized complete block design (RCBD). Three replicates were employed with 5 jars in each replicate. Data were recorded after 3 weeks on hyperhydricity percentage, number of shoots per explant, shoot length $(\mathrm{cm})$ and number of leaves per shoot.

\section{In vitro rooting of shootlets}

Uniform individual shoots $(\sim 3-4 \mathrm{~cm}$ long each) derived from the multiplication stage were transferred to different rooting media comprising three different strengths of MS basal salts (full, $1 / 2$ and $1 / 4 \mathrm{MS}$ ) in combination with three concentrations of sucrose $(15,20,25$ and 30 $\mathrm{g} / \mathrm{l})$. All media were PGRs-free. The treatments were arranged in $3 \times 4$ factorial experiment in randomized complete block design (RCBD). Three replicates were employed with 5 jars in each replicate. Data were recorded after 3 weeks on rooting percentage, number of roots per shoot and root length $(\mathrm{cm})$.

\section{Acclimatization of the plantlets}

The well rooted plantlets were carefully removed from the culture medium and the roots were gently washed in sterile distilled water to remove the agar. The plantlets where then transferred into plastic pots $(15-\mathrm{cm}$ in diameter) containing one of the following three autoclaved media, clay, peatmoss + perlite $(1: 1$ $\mathrm{v}: \mathrm{v})$ or peatmoss + vermiculite + perlite $(1: 1: 1$ by volume). Three replicates were employed and each treatment consisted of 3 pots and each pot contained one plantlet and covered with transparent polyethylene plastic sheet to maintain high relative humidity around plants. The plastic cover was gradually removed starting from one week after transplanting in order to get rid of excess humidity as well as expose the plantlets to ex vitro conditions. The plantlets were irrigated with tap water whenever needed. Data were recorded after 4 weeks on survival percentage and average increase in shoot length $(\mathrm{cm})$.

\section{Statistical analysis}

Data of all experiments was subjected to analysis of variance (ANOVA) and mean comparison were performed using the least significant difference (LSD) method with a significant level of 5\% (Gomez and Gomez, 1984).

\section{$\underline{\text { Results and Discussion }}$}

\section{Callus induction from leaves of in vitro-} germinated seeds

Callus was induced from leaves of in vitrogerminated seeds of petunia only on the media amended with any combination of NAA and/or 
BAP in varying concentrations. Meanwhile, the PGRs-free medium did not produce callus (Table 1). The induced callus was compact green in all cases (Fig.1.D). The results obtained indicate that the presence of both auxins and cytokinins is essential for callus formation. Significant differences were recorded among various concentrations of BAP. It was noticed that tendency to callusing increased as the BAP concentration was increased reaching its highest value $(30 \%)$ when $0.5 \mathrm{mg} / 1 \mathrm{BAP}$ was employed. Increasing the BAP concertation to $1.0 \mathrm{mg} / \mathrm{l}$ led to a significant decline in callusing percentage $(20 \%)$. Regarding the auxin application, the differences between NAA at $0.1 \mathrm{mg} / 1$ and the control (PGR-free) were significant. The interaction between BAP and NAA showed significant differences as well. Supplementing the medium with BAP at $0.5 \mathrm{mg} / 1$ in combination with NAA at $0.1 \mathrm{mg} / 1$ resulted in the highest percentage for explants producing callus $(40 \%)$. These results are consistent with the well-known fact that callus induction is promoted through the application of intermediate ratio of auxin and cytokinin, while a high ratio of auxin-to-cytokinin or cytokinin-to-auxin induces root and shoot regeneration, respectively. Inclusion of NAA in the callus induction medium of Petunia hybrida has been reported in concentrations ranging from 0.1 to $0.2 \mathrm{mg} / 1$ by some authors such as Su-ping (2001) and Xian-Chun (2010). In addition to NAA, BAP in a concentration up to $1.0 \mathrm{mg} / \mathrm{l}$ has been a common cytokinin recommended for Petunia hybrid in callus induction media by several authors such as Jin et al., (2007), Fan et al., (2009) and Kaviani \& Kazemi (2017).

Shoot organogenesis from callus explants

Different types of cytokinins revealed significantly variable effects on shoot regeneration form callus of Petunia hybrida obtained from the previous step (Fig 1 E \& $\mathrm{F})$. Regeneration percentage ranged from 40 to $90 \%$ when callus was cultured on MS medium with or without PGRs (Table 2). The addition of cytokinin (Kin, BAP and TDZ) at any concentration significantly increased the regeneration percentage as compared to regeneration on the PGRs-free medium, except for high concentrations of TDZ ( 0.8 and 1.0 $\mathrm{mg} / \mathrm{l})$ which had lower regeneration \% than the control. Generally, calluses cultured on kinetin-supplemented medium had the highest regeneration percentage $(76.67 \%)$, followed by BAP (71.66) then TDZ (64.45\%). Meanwhile, BAP produced the highest number of shoots, shoot length and leaf number/shoots as compared with Kin or TDZ (Table 2).

TABLE 1. Effect of different concentrations of BAP and NAA on callus induction from leaf explants of Petunia hybrid after 21 days in culture

\begin{tabular}{|c|c|c|c|c|c|c|c|c|c|}
\hline \multirow{2}{*}{$\begin{array}{l}\text { NAA } \\
\mathrm{mg} / \mathrm{l}\end{array}$} & \multicolumn{5}{|c|}{ Explants producing callus \% } & \multicolumn{4}{|c|}{ Visual observations } \\
\hline & 0.00 & 0.25 & 0.50 & 1.00 & Mean & 0.00 & 0.25 & 0.50 & 1.00 \\
\hline 0.0 & 0.00 & 10.00 & 20.00 & 10.00 & 10.00 & $\begin{array}{c}\text { No } \\
\text { response }\end{array}$ & $\begin{array}{l}\text { Green } \\
\text { callus }\end{array}$ & $\begin{array}{l}\text { Green } \\
\text { callus }\end{array}$ & $\begin{array}{c}\text { Compact } \\
\text { green } \\
\text { Callus }\end{array}$ \\
\hline 0.1 & 0.00 & 33.33 & 40.00 & 30.00 & 25.80 & $\begin{array}{c}\text { No } \\
\text { response }\end{array}$ & $\begin{array}{c}\text { Compact } \\
\text { green } \\
\text { callus }\end{array}$ & $\begin{array}{c}\text { Compact } \\
\text { green } \\
\text { Callus }\end{array}$ & $\begin{array}{c}\text { Compact } \\
\text { green } \\
\text { Callus }\end{array}$ \\
\hline Mean & 0.00 & 21.70 & 30.00 & 20.00 & & & & & \\
\hline \multicolumn{10}{|l|}{ LSD 0.05} \\
\hline BAP & & & 2.50 & & & & & & \\
\hline NAA & & & 1.77 & & & & & & \\
\hline BAP x NAA & & & 3.53 & & & & & & \\
\hline
\end{tabular}




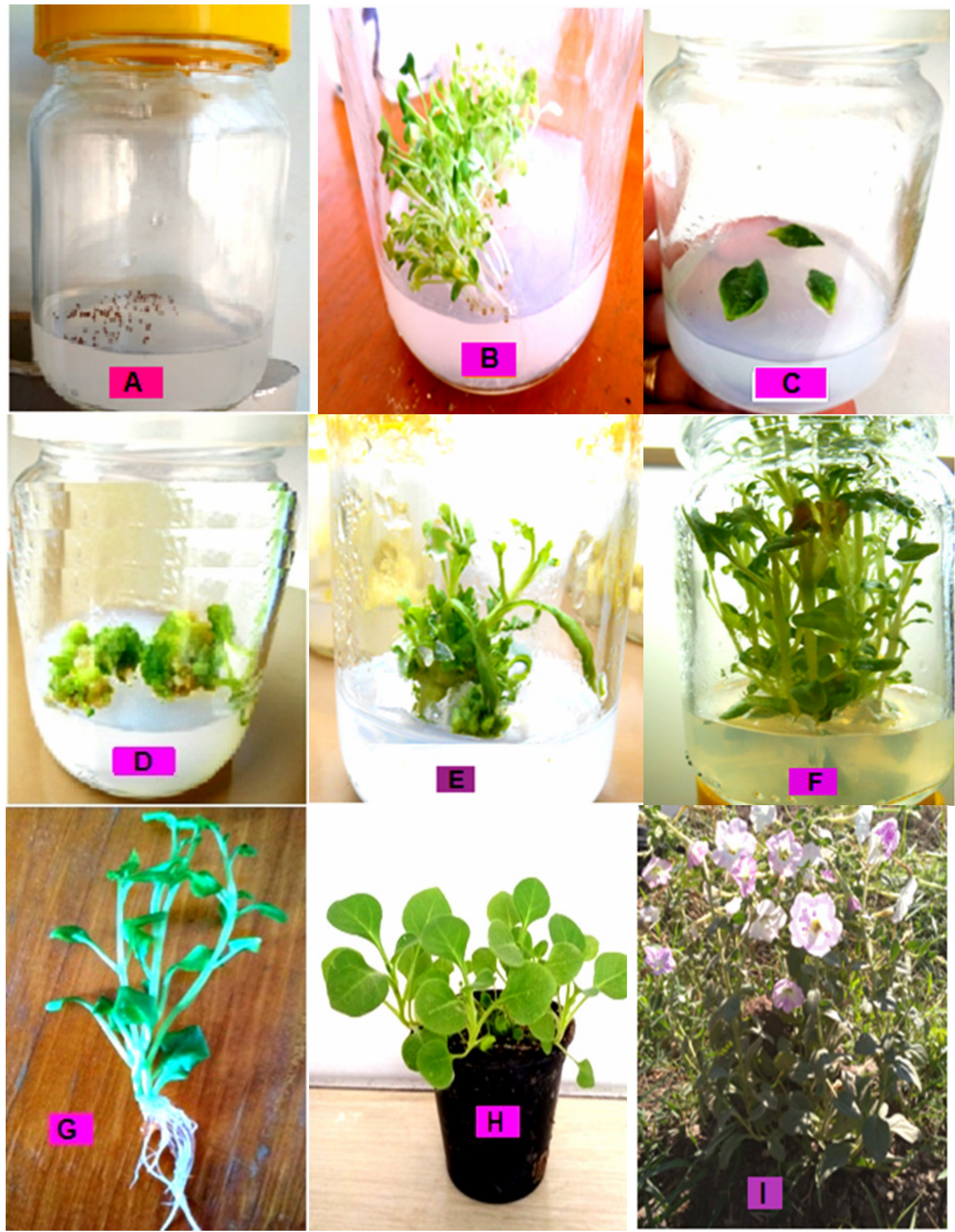

Fig. 1. Steps of callus induction from in vitro germinated seeds and shoot organogenesis of Petunia hybrida. (A) aseptically cultured seeds on PGRs-free MS medium, (B) germinated seeds, (C) cultured leaf explants for callus induction, (D) callus formed after 3 weeks from leaves on callus induction media containing 0.5 BAP and 0.1NAA (E) adventitious shoots regenerated from callus cultured on medium supplemented with 0.8 mg/l TDZ after 4 weeks (F) Adventitious shoot multiplication on medium with 0.2 BAP after 3 weeks, (G) Rooting of isolated single shoot on 1/2 MS medium with $15 \mathrm{~g}$ sucrose/l, (H) Acclimatized plantlets transferred to plastic pots filled with clay after 2 months, (I) Flowering petunia plants after 3 months of transferring to the field. 
TABLE 2. Effect of cytokinin type and concentration on shoots regeneration from callus explants of Petunia hybrid after 4 weeks in culture.

\begin{tabular}{|c|c|c|c|c|c|c|c|}
\hline \multicolumn{2}{|c|}{ Treatments } & \multicolumn{6}{|c|}{ Parameters } \\
\hline $\begin{array}{l}\text { Cytokinin } \\
\text { type }\end{array}$ & $\begin{array}{c}\text { Concentrations } \\
\mathrm{mg} / \mathrm{l}\end{array}$ & $\begin{array}{c}\text { Regene- } \\
\text { ration } \\
\%\end{array}$ & $\begin{array}{l}\text { Explants } \\
\text { forming } \\
\text { callus \% }\end{array}$ & $\begin{array}{c}\text { Hyper- } \\
\text { hydricity } \\
\%\end{array}$ & $\begin{array}{c}\text { Shoot } \\
\text { number/ } \\
\text { explant }\end{array}$ & $\begin{array}{l}\text { Shoot } \\
\text { length } \\
\text { cm }\end{array}$ & $\begin{array}{c}\text { Leaf } \\
\text { number/ } \\
\text { explant }\end{array}$ \\
\hline \multirow[t]{7}{*}{ BAP } & 0.0 & 60.00 & 10.00 & 20.00 & 1.00 & 3.33 & 4.17 \\
\hline & 0.2 & 73.30 & 30.00 & 36.67 & 2.61 & 4.47 & 7.11 \\
\hline & 0.4 & 70.00 & 40.00 & 43.30 & 2.28 & 4.12 & 7.33 \\
\hline & 0.6 & 76.67 & 53.30 & 46.70 & 2.19 & 4.00 & 7.22 \\
\hline & 0.8 & 80.00 & 50.00 & 50.00 & 1.97 & 3.10 & 6.50 \\
\hline & 1.0 & 70.00 & 63.30 & 50.00 & 1.64 & 2.27 & 4.33 \\
\hline & mean & 71.66 & 41.10 & 41.11 & 1.95 & 3.55 & 6.11 \\
\hline \multirow[t]{7}{*}{ TDZ } & 0.0 & 60.00 & 10.00 & 20.00 & 1.00 & 3.33 & 4.17 \\
\hline & 0.2 & 76.70 & 43.30 & 40.00 & 1.41 & 2.90 & 5.60 \\
\hline & 0.4 & 86.70 & 50.00 & 53.30 & 2.08 & 3.10 & 6.83 \\
\hline & 0.6 & 70.00 & 73.30 & 50.00 & 1.83 & 2.47 & 6.50 \\
\hline & 0.8 & 53.30 & 70.00 & 60.00 & 1.75 & 2.32 & 5.00 \\
\hline & 1.0 & 40.00 & 60.00 & 50.00 & 1.50 & 1.53 & 4.50 \\
\hline & mean & 64.45 & 51.10 & 45.55 & 1.60 & 2.61 & 5.43 \\
\hline \multirow[t]{7}{*}{ Kin } & 0.0 & 60.00 & 10.00 & 20.00 & 1.00 & 3.33 & 4.17 \\
\hline & 0.2 & 90.00 & 40.00 & 63.30 & 1.33 & 2.57 & 6.00 \\
\hline & 0.4 & 90.00 & 60.00 & 50.00 & 2.22 & 3.25 & 8.50 \\
\hline & 0.6 & 80.00 & 63.30 & 60.00 & 2.00 & 2.70 & 5.43 \\
\hline & 0.8 & 70.00 & 60.00 & 66.70 & 2.08 & 2.30 & 4.5 \\
\hline & 1.0 & 70.00 & 76.70 & 70.00 & 1.66 & 2.10 & 4.00 \\
\hline & mean & 76.67 & 51.67 & 55.00 & 1.72 & 2.71 & 5.43 \\
\hline \multicolumn{8}{|c|}{ means of Concentrations } \\
\hline & 0.0 & 60.00 & 10.00 & 20.00 & 1.00 & 3.33 & 4.17 \\
\hline & 0.2 & 80.00 & 37.77 & 46.66 & 1.78 & 3.31 & 6.24 \\
\hline & 0.4 & 82.23 & 50.00 & 48.87 & 2.19 & 3.49 & 7.55 \\
\hline & 0.6 & 75.56 & 63.30 & 52.23 & 2.01 & 3.06 & 6.38 \\
\hline & 0.8 & 67.77 & 60.00 & 58.90 & 1.93 & 2.57 & 5.33 \\
\hline & 1.0 & 60.00 & 66.67 & 56.67 & 1.60 & 1.97 & 4.28 \\
\hline \multirow{3}{*}{ LSD 0.05} & Cytokinins & 3.50 & 2.28 & 2.29 & 0.15 & 0.22 & 0.32 \\
\hline & Concentrations & 4.94 & 3.23 & 3.24 & 0.21 & 0.31 & 0.46 \\
\hline & Interaction & 8.57 & 5.59 & 5.61 & 0.37 & 0.53 & 0.79 \\
\hline
\end{tabular}

Egypt. J. Hort. Vol. 46, No.1 (2019) 
These results indicate that purine-based cytokinins are more suitable for inducing higher bud regeneration comparing to TDZ. Efficiency of BAP in indirect shoot organogenesis is supported by several recent publications on Petunia hybrida such as (Abu-Qaoud et al., 2010, Burbulis et al., 2015, Fan et al., 2009, and Kaviani \& Kazemi 2017). Previous studies reported a positive effect of Kin on regeneration of many other plant species such as Salix viminalis (Grendysz et al., 2017), and cumin (Tawfik and Noga, 2002). Many other studies have reported successful shoot regeneration from petunia leaf explants when cultured on medium containing TDZ alone (Abu-Qaoud, 2012, Thirukkumaran et al., 2009). They attributed that to the effect of TDZ when included in the medium resulting in a balanced ratio of endogenous PGR that allows for specific modes of regeneration to take place, which is likely dependent on concentration as well as the plant species. Poor elongation of TDZ induced shoots has also been reported, probably due to its high cytokinin activity which is highly dependent on the concentration and duration of exposure to this compound (Mohamed et al., 1992 and Murthy et al., 1998).

Lower concentrations of cytokinin (0.2 and $0.4 \mathrm{mg} / \mathrm{l})$ led to the highest regeneration percentage ( 80.0 and $82.23 \%$ respectively), which declined with the increase in the concentration. Using $0.4 \mathrm{mg} / 1$ from any of the cytokinins produced the best results regarding number of shoots/explant (2.19), shoot length $(3.49 \mathrm{~cm})$ and leaf number (7.55).

Concerning the interaction effect, the two lower concentrations $(0.2$ and $0.4 \mathrm{mg} / \mathrm{l})$ of both Kin and TDZ recorded the highest regeneration percentage. However, the increase in BAP concentration led to an increase in the regeneration $\%$ reaching the highest values $(80 \%)$ with $0.8 \mathrm{mg} / 1$ which decreased when $1.0 \mathrm{mg} / \mathrm{l}$ was used (Table 2). The lowest concentration of BAP $(0.2 \mathrm{mg} / \mathrm{l})$ exerted the best results with respect to number of shoots, shoot length and leaf number/shoots, whilst the higher concentration $(0.4 \mathrm{mg} / \mathrm{l})$ of both Kin and TDZ showed the best results. In consistence with the current experiment results BAP at a concentration ranging from 0.4 to $0.8 \mathrm{mg} / 1$ was reported by Burbulis et al., (2015) to induce the highest explant regeneration frequency in different cultivars of Petunia hybrida.
Effect of cytokinin type and concentration on axillary shoot multiplication

The regenerated adventitious shoots from the previous step were multiplied on MS medium supplemented with the same three types and concentrations of cytokinins (BAP, Kin and TDZ). Response of the cultured explants (microcuttings) varied in a significant way according to the type of cytokinin where BAP-amended medium exhibited the best results regarding multiplication capacity, number of shoots/explant (7.76 shoots), shoot length $(3.95 \mathrm{~cm})$ and number of leaves/explant (24,14 leaves) (Table 3$)$. TDZ exerted better results than Kin with respect to multiplication capacity and shoot length, whereas Kin induced more shoots/explants and more leaves/ explant than TDZ. Capability of TDZ to boost multiplication capacity has been previously reported by several authors on petunia (AbuQaoud, 2012 and Thirukkumaran et al., 2009) as well as many other plant species (Corredoira et al., 2008, and Sanikhani et al., 2006). However, the shoots induced by TDZ are short as has been reported in some plant species such as beans (Mohamed et al., 1992) and apple (Van Nieuwkerk et al.,1986). Inhibition of shoot elongation could be attributed to its high cytokinin concentrations (Huetteman \& Preece, 1993 and Mohamed et al., 1992).

Multiplication capacity as well as number of shoots formed and their characteristics on cytokinin-free medium (control) were significantly improved when shoots were cultured on cytokinin enriched medium (Table 3 ). This effect reached its peak at the lowest concentration $(0.2 \mathrm{mg} / \mathrm{l})$ which significantly declined as the concentration was increased reaching the lowest valued when the highest concentration was used. On the contrary, increasing the concentration of the cytokinins led to significantly higher callogenesis as well as hyperhydricity percentage.

The interaction between cytokinin type and concentration showed a significant variation in all characteristics except the multiplication capacity. Using BAP $(0.2 \mathrm{mg} / \mathrm{l})$ or TDZ $(0.2$ or $04 \mathrm{mg} / \mathrm{l})$ induced the highest multiplication capacity $(90 \%)$. Furthermore, BAP at $0.2 \mathrm{mg} / \mathrm{l}$ was far superior to all other treatments attaining the highest number of shoots/explant (14.50), the longest shoot (5 $\mathrm{cm})$ and the highest number of leaves per explant (46.07). 
TABLE 3. Effect of cytokinin type and concentration on multiplication of regenerated shoots of Petunia hybrid after 4 weeks in culture.

\begin{tabular}{|c|c|c|c|c|c|c|c|}
\hline \multicolumn{2}{|c|}{ Treatments } & \multirow[b]{2}{*}{$\begin{array}{c}\text { Multipl- } \\
\text { ication } \\
\text { capacity } \\
\%\end{array}$} & \multicolumn{4}{|c|}{ Parameters } & \multirow[b]{2}{*}{$\begin{array}{c}\text { Leaf } \\
\text { number/ } \\
\text { explant }\end{array}$} \\
\hline $\begin{array}{l}\text { Cytokinin } \\
\text { type }\end{array}$ & $\begin{array}{l}\text { Concentrations } \\
\mathrm{mg} / \mathrm{l}\end{array}$ & & $\begin{array}{l}\text { Explantsforming } \\
\text { callus \% }\end{array}$ & $\begin{array}{c}\text { Hyper- } \\
\text { hydricity } \\
\%\end{array}$ & $\begin{array}{c}\text { Shoot } \\
\text { number/ } \\
\text { explant }\end{array}$ & $\begin{array}{c}\text { Shoot } \\
\text { length } \\
\text { cm }\end{array}$ & \\
\hline \multirow[t]{7}{*}{ BAP } & 0.0 & 73.30 & 20.00 & 30.00 & 1.00 & 3.67 & 3.17 \\
\hline & 0.2 & 90.00 & 30.00 & 40.00 & 14.50 & 5.00 & 46.07 \\
\hline & 0.4 & 86.67 & 30.00 & 46.70 & 12.70 & 4.70 & 37.94 \\
\hline & 0.6 & 80.00 & 40.00 & 50.00 & 9.83 & 3.90 & 28.83 \\
\hline & 0.8 & 70.00 & 53.33 & 53.30 & 5.50 & 3.50 & 18.00 \\
\hline & 1.0 & 63.30 & 60.00 & 53.30 & 3.00 & 2.90 & 10.83 \\
\hline & mean & 77.21 & 38.89 & 45.55 & 7.76 & 3.95 & 24.14 \\
\hline \multirow[t]{7}{*}{ TDZ } & 0.0 & 73.30 & 20.00 & 30.00 & 1.00 & 3.67 & 3.17 \\
\hline & 0.2 & 90.00 & 40.00 & 40.00 & 7.00 & 3.82 & 19.67 \\
\hline & 0.4 & 90.00 & 33.33 & 50.00 & 7.77 & 4.07 & 21.33 \\
\hline & 0.6 & 80.00 & 43.33 & 53.30 & 3.70 & 3.75 & 12.17 \\
\hline & 0.8 & 70.00 & 56.67 & 60.00 & 3.33 & 3.62 & 10.00 \\
\hline & 1.0 & 53.30 & 60.00 & 56.70 & 1.83 & 2.32 & 3.50 \\
\hline & mean & 76.10 & 42.22 & 48.33 & 4.11 & 3.54 & 11.64 \\
\hline \multirow[t]{7}{*}{ Kin } & 0.0 & 73.33 & 20.00 & 30.00 & 1.00 & 3.67 & 3.17 \\
\hline & 0.2 & 83.33 & 36.70 & 20.00 & 6.00 & 3.77 & 20.33 \\
\hline & 0.4 & 86.67 & 53.30 & 23.30 & 6.83 & 3.80 & 23.67 \\
\hline & 0.6 & 70.00 & 56.70 & 40.00 & 5.67 & 2.85 & 20.00 \\
\hline & 0.8 & 53.33 & 66.70 & 53.30 & 4.67 & 2.23 & 14.33 \\
\hline & 1.0 & 50.00 & 70.00 & 46.70 & 2.33 & 1.93 & 8.70 \\
\hline & mean & 69.44 & 50.57 & 35.55 & 4.42 & 3.04 & 15.03 \\
\hline \multicolumn{8}{|c|}{ means of Concentrations } \\
\hline & 0.0 & 73.31 & 20.00 & 30.00 & 1.00 & 3.67 & 3.17 \\
\hline & 0.2 & 87.78 & 35.57 & 33.33 & 9.17 & 4.20 & 28.69 \\
\hline & 0.4 & 87.78 & 38.88 & 40.00 & 9.10 & 4.19 & 27.65 \\
\hline & 0.6 & 76.67 & 46.68 & 47.77 & 6.40 & 3.50 & 20.33 \\
\hline & 0.8 & 64.44 & 58.90 & 55.53 & 4.50 & 3.12 & 14.11 \\
\hline & 1.0 & 55.53 & 63.33 & 52.23 & 2.39 & 2.38 & 7.68 \\
\hline \multirow{3}{*}{ LSD 0.05} & Cytokinins & 4.24 & 2.65 & 2.65 & 0.35 & 0.13 & 1.26 \\
\hline & Conc. & 5.99 & 3.75 & 3.74 & 0.49 & 0.18 & 1.78 \\
\hline & Interaction & NS & 6.50 & 6.48 & 0.85 & 0.32 & 3.09 \\
\hline
\end{tabular}

*NS denotes non-significant differences using ANOVA $(P<0.05)$.

Egypt. J. Hort. Vol. 46, No.1 (2019) 
Effect of repeated subculturing and cytokinins on axillary shoot multiplication

Repeated subculturing showed significant effects on multiplication capacity, number of shoots/explant, shoot length and number of leaves per explant. Comparing to the first subculture, all the recorded characteristics showed a significant improvement in the second and the third subcultures, then a significant reduction was clear in the fourth subculture (Table 4).
The three cytokinin treatments tested showed non-significant differences regarding multiplication capacity. In accordance with the results recorded in the previous experiment, it is clear that BAP exerted the best results concerning number of shoots/explant (11.33), shoot length $(5.65 \mathrm{~cm})$ and number of leaves/ explant (32.93) followed by TDZ then Kin, respectively (Table 4).

TABLE 4. Effect of repeated subculturing and cytokinins on axillary shoot multiplication of regenerated shoots of Petunia hybrid after 3 weeks in culture.

\begin{tabular}{|c|c|c|c|c|c|c|c|}
\hline \multicolumn{2}{|c|}{ Treatments } & \multicolumn{6}{|c|}{ Parameters } \\
\hline $\begin{array}{l}\text { Subculture } \\
\text { passage }\end{array}$ & $\begin{array}{l}\text { Cytokinin } \\
(\mathrm{mg} / \mathrm{l})\end{array}$ & $\begin{array}{c}\text { Multipl- } \\
\text { ication } \\
\text { capacity } \\
\% \\
\end{array}$ & $\begin{array}{l}\text { Explants } \\
\text { forming } \\
\text { callus \% }\end{array}$ & $\begin{array}{c}\text { Hyper- } \\
\text { hydricity } \\
\%\end{array}$ & $\begin{array}{c}\text { Shoot } \\
\text { number/ } \\
\text { explant }\end{array}$ & $\begin{array}{c}\text { Shoot } \\
\text { length } \\
\text { cm }\end{array}$ & $\begin{array}{c}\text { Leaf } \\
\text { number/ } \\
\text { explant }\end{array}$ \\
\hline \multirow[t]{4}{*}{ First } & $\operatorname{BAP}(0.2)$ & 90.00 & 30.00 & 43.30 & 9.50 & 5.40 & 30.33 \\
\hline & $\operatorname{TDZ}(0.4)$ & 90.00 & 40.00 & 30.00 & 8.20 & 4.93 & 20.70 \\
\hline & Kin $(0.4)$ & 93.30 & 43.30 & 36.70 & 7.33 & 3.67 & 21.00 \\
\hline & mean & 91.10 & 37.77 & 36.67 & 8.34 & 4.67 & 24.01 \\
\hline \multirow[t]{4}{*}{ Second } & $\operatorname{BAP}(0.2)$ & 96.70 & 10.00 & 30.00 & 11.00 & 5.51 & 36.7 \\
\hline & $\operatorname{TDZ}(0.4)$ & 100.00 & 26.70 & 33.30 & 9.33 & 4.50 & 27.00 \\
\hline & Kin $(0.4)$ & 93.30 & 20.00 & 36.70 & 7.33 & 4.10 & 24.30 \\
\hline & mean & 96.67 & 18.90 & 33.33 & 9.22 & 4.70 & 29.33 \\
\hline \multirow[t]{4}{*}{ Third } & $\operatorname{BAP}(0.2)$ & 93.33 & 0.00 & 20.00 & 14.00 & 6.52 & 39.70 \\
\hline & $\operatorname{TDZ}(0.4)$ & 93.33 & 0.00 & 20.00 & 10.33 & 5.22 & 26.00 \\
\hline & Kin $(0.4)$ & 100.00 & 0.00 & 33.30 & 7.50 & 4.33 & 24.33 \\
\hline & mean & 95.55 & 0.00 & 24.43 & 10.61 & 5.36 & 30.01 \\
\hline \multirow[t]{4}{*}{ Fourth } & $\operatorname{BAP}(0.2)$ & 90.00 & 0.00 & 10.00 & 10.83 & 5.15 & 25.00 \\
\hline & $\operatorname{TDZ}(0.4)$ & 86.70 & 0.00 & 23.33 & 8.67 & 4.10 & 19.00 \\
\hline & Kin $(0.4)$ & 83.30 & 0.00 & 20.00 & 6.50 & 3.82 & 10.00 \\
\hline & mean & 86.67 & 0.00 & 17.78 & 8.67 & 4.36 & 18.00 \\
\hline \multicolumn{8}{|c|}{ means of Cytokinin $(\mathrm{mg} / \mathrm{l})$} \\
\hline & $\operatorname{BAP}(0.2)$ & 92.51 & 10.00 & 25.83 & 11.33 & 5.65 & 32.93 \\
\hline & $\operatorname{TDZ}(0.4)$ & 92.51 & 16.68 & 26.66 & 9.13 & 4.69 & 23.18 \\
\hline & Kin $(0.4)$ & 92.48 & 15.83 & 31.68 & 7.17 & 3.98 & 19.91 \\
\hline \multirow{3}{*}{ LSD 0.05} & Subculture & 5.32 & 3.14 & 5.87 & 1.03 & 0.32 & 2.48 \\
\hline & Cytokinin & NS & 2.04 & 3.23 & 0.93 & 0.15 & 2.50 \\
\hline & Interaction & NS & 4.10 & 6.45 & 1.87 & 0.29 & $\mathrm{NS}^{*}$ \\
\hline
\end{tabular}

*NS denotes non-significant differences using ANOVA $(P<0.05)$. 
The least incidence of callogenesis and hyperhydricity was observed in the explants cultured on BAP-supplemented medium in the four subcultures. During the third subculture, BAP-supplemented medium also induced the highest number of shoots per explants (14.00), the longest shoots (6.52) and the highest number of leaves explant (39.7), this combined treatment was followed by the same medium in the second subculture.

In accordance with our results, several previous investigations have reported an initial increase in the number of shoots per explant with each subculture which decreased later after several subcultures of Gladiolus hybridus (Aftab et al., 2008), Vitex negundo (Rani and Nair, 2006) and Euphorbia tirucalli (Uchida et al., 2004).

Effect of basal salt strength and sucrose concentrations on axillary shoot multiplication

Strength of MS basal salt, showed significant effect during the multiplication stage of Petunia hybrida. In all the previous experiments conducted in this study, full strength MS basal salts was employed. To test the possibility of using lower strength, and accordingly lower cost, without a significant adverse effect on multiplication performance, different strengths of MS (full, 3/4, 1/2 and $1 / 4$ strength) were compared. Lowering the strength led to a significant reduction in the hyperhydricity percentage from 37.77 in full MS to 6.67 in $1 / 4$ MS which means a significant advantage during the multiplication stage. Nevertheless, lowering basal salt strength caused a significant reduction in number of shoots and leaves and shoot length. This indicating that increasing basal salt strength is essential for improving multiplication performance of petunia. Consistent to these results, Villamor (2010) demonstrated that the full strength medium induced the highest number of shoots of in vitrogrown Zingiber officinalis while decreasing the medium strength led to a significant decline in number of shoots.

On the other hand, when sucrose concentration was increased, hyperhydricity and shoot length were decreased while number of shoots and leaves were significantly increased. This indicates that high sucrose concentration is needed in the multiplication medium of Petunia hybrida. Several previous reports have mentioned the difference between species, in the optimum concentration of sucrose required to induce morphogenesis or growth (George et al.,
2008, Tawfik, et al., 2018 and Tawfik, 1995). In his experiment on petunia, Raquin (1983) stated that, culture medium must contain a metabolizable sugar to allow the growth of petunia explant. This is clearly because of the carbohydrate supply required by plant cell, tissue and organ cultures in order to satisfy energy demands (de Paiva Neto and Otoni, 2003). Although the best morphogenic response under the current experiment conditions was induced using the highest levels of sucrose, a reduction in shoot length was recorded. This could imply that using higher concentrations of sucrose than $40 \mathrm{~g} / \mathrm{l}$ (the highest concentrations employed) might cause adverse influence on multiplication which could be attributed to the excessive osmotic contribution or by toxicity of the carbohydrate occurred at high concentrations (de Paiva Neto and Otoni, 2003). In agreement with the results obtained under the current experiment's conditions, (Zimmerman and Cobb, 1989) stated that increased sucrose concentrations promoted hyperhydricity in tissue cultures of petunia.

The interaction between the strength of basal salt and the concentration of sucrose exerted significant variation. Using $1 / 4 \mathrm{MS}$ with 30 or 40 $\mathrm{g} / 1$ sucrose or $1 / 2 \mathrm{MS}$ with $40 \mathrm{~g} / 1$ sucrose exhibited no hyperhydricity. Meanwhile, employing the highest basal salt strength (Full MS) with the highest concentration of sucrose $(40 \mathrm{~g} / \mathrm{l})$ boosted multiplication performance recording the highest number of shoots per explant (12.00) and number of leaves per shoot (32.70), with no significant differences. Using $3 / 4 \mathrm{MS}$ with $30 \mathrm{~g} / 1$ sucrose produced the longest shoots (4.63) (Tables 5 and $6)$. The mutual effect between the concentration of both sucrose and the basal medium has been previously discussed by several authors. Using culture media with inorganic salts in different concentrations results in a considerable alteration of the osmotic potential of the culture medium. Previous reports indicated that sucrose is hydrolyzed after autoclaving the medium (Pan and Van Staden, 1999, Schenk et al., 1991). Investigating what happens during autoclaving MS salts solution, they recorded a reduction of $\mathrm{pH}$ as a consequence of the ionization of the salts causing sucrose hydrolysis. These results confirm the interaction between the concentration of basal medium and sucrose (de Paiva Neto and Otoni, 2003). It was also noticed that increasing the sucrose concentration in the medium lead to elevating respiration rate of the plant tissues thus increasing the uptake of inorganic ions (George et al., 2008). 
TABLE 5. Effect of MS basal salt strength and sucrose concentration on Hyperhydricity \% and shoot number/ explant during multiplication stage of Petunia hybrid after 3 weeks in culture.

\begin{tabular}{|c|c|c|c|c|c|c|c|c|c|}
\hline \multirow{2}{*}{$\begin{array}{l}\text { MS } \\
\text { medium } \\
\text { strength }\end{array}$} & \multirow[t]{2}{*}{$\begin{array}{c}\text { Sucrose } \\
\text { g/l }\end{array}$} & \multicolumn{4}{|c|}{ Hyperhydricity \% } & \multicolumn{4}{|c|}{ Shoot number/explant } \\
\hline & & 20 & 30 & 40 & mean & 20 & 30 & 40 & mean \\
\hline Full & & 50.00 & 43.30 & 20.00 & 37.77 & 8.33 & 11.00 & 12.00 & 10.44 \\
\hline $3 / 4$ & & 50.00 & 36.70 & 20.00 & 35.57 & 7.00 & 9.50 & 10.00 & 8.83 \\
\hline $1 / 2$ & & 43.30 & 20.00 & 0.00 & 21.10 & 5.00 & 7.00 & 7.00 & 6.33 \\
\hline $1 / 4$ & & 20.00 & 0.00 & 0.00 & 6.67 & 2.70 & 3.30 & 3.00 & 3.00 \\
\hline mean & & 40.83 & 25.00 & 10.00 & & 5.76 & 7.70 & 8.00 & \\
\hline
\end{tabular}

LSD 0.05

$\begin{array}{rrr}\text { MS strength } & 3.97 & 1.04 \\ \text { Sucrose } & 3.44 & 0.90 \\ \text { Interaction } & 6.88 & \mathrm{NS}^{*}\end{array}$

*NS denotes non-significant differences using ANOVA $(P<0.05)$.

TABLE 6. Effect of MS basal salt strength and sucrose concentration on shoot length and leaf number during multiplication stage of Petunia hybrid after 3 weeks in culture.

\begin{tabular}{|c|c|c|c|c|c|c|c|c|c|}
\hline \multirow{2}{*}{$\begin{array}{l}\text { MS } \\
\text { medium } \\
\text { strength }\end{array}$} & \multirow[t]{2}{*}{$\begin{array}{c}\text { Sucrose } \\
\text { g/l }\end{array}$} & \multicolumn{4}{|c|}{ Shoot length $(\mathrm{cm})$} & \multicolumn{4}{|c|}{ Leaf number/shoot } \\
\hline & & 20 & 30 & 40 & mean & 20 & 30 & 40 & mean \\
\hline Full & & 4.9 & 4.33 & 4.12 & 4.45 & 25 & 28 & 32.7 & 28.57 \\
\hline $3 / 4$ & & 5.20 & 4.63 & 4.60 & 4.81 & 24 & 28 & 30 & 27.33 \\
\hline $1 / 2$ & & 4.13 & 3.8 & 3.6 & 3.84 & 19 & 23 & 21.3 & 21.1 \\
\hline $1 / 4$ & & 2.8 & 3.5 & 3.3 & 3.20 & 11 & 12 & 12 & 11.67 \\
\hline mean & & 4.26 & 4.07 & 3.91 & & 19.75 & 22.75 & 24 & \\
\hline
\end{tabular}

LSD 0.05

$\begin{array}{rcc}\text { MS strength } & 0.19 & 2.55 \\ \text { Sucrose } & 0.16 & 2,21 \\ \text { Interaction } & 0.32 & \mathrm{NS}^{*}\end{array}$

*NS denotes non-significant differences using ANOVA $(P<0.05)$.

\section{Rooting of microshoots}

Rooting percentage, number of roots and root length increased when MS strength was reduced from full to $1 / 2$ strength recording the highest results $(86.68 \%, 7.68$ roots $/$ shoot and $9.88 \mathrm{~cm}$, respectively). These values were significantly reduced when $1 / 4 \mathrm{MS}$ strength was used reaching even significantly lower results than those induced by full MS (Tables 7 and 8). The enhancement in rooting behavior observed when MS strength was reduced from full to $1 / 2$ could be interpreted according to the fact that high salt levels are frequently inhibitory to root initiation. This is why media known with small osmotic potential are favorable for root induction and growth under in vitro conditions (George et al., 2008). 
TABLE 7. Effect of MS basal salt strength and sucrose concentration on in vitro rooting percentage of Petunia hybrid after 3 weeks in culture.

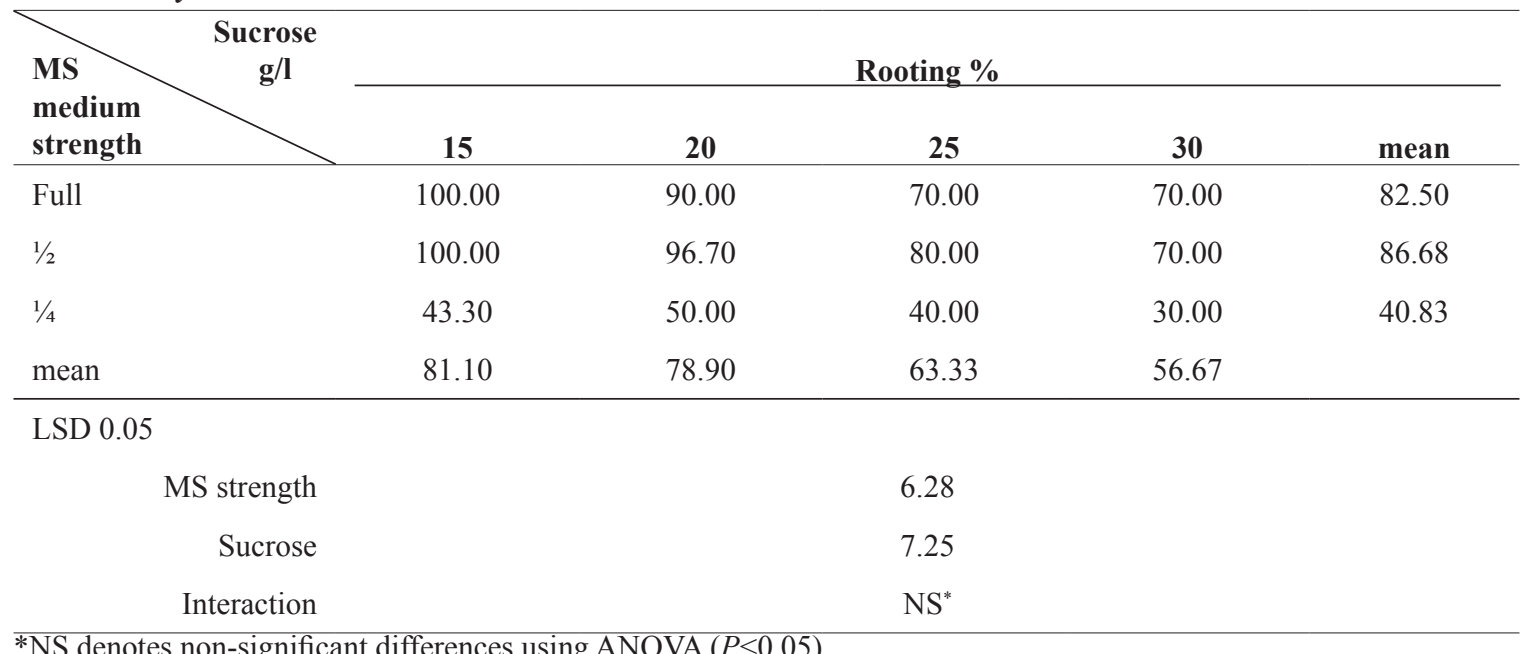

*NS denotes non-significant differences using ANOVA $(P<0.05)$.

TABLE 8. Effect of MS basal salt strength and sucrose concentration on root number and root length of Petunia hybrid after 3 weeks in culture.

\begin{tabular}{|c|c|c|c|c|c|c|c|c|c|c|}
\hline \multirow{2}{*}{ medium } & \multicolumn{5}{|c|}{ Root number/shoot } & \multicolumn{5}{|c|}{ Root length (cm) } \\
\hline & 15 & 20 & 25 & 30 & mean & 15 & 20 & 25 & 30 & mean \\
\hline Full & 7.20 & 6.50 & 6.20 & 5.50 & 6.35 & 9.50 & 7.50 & 7.00 & 6.50 & 7.63 \\
\hline $1 / 2$ & 8.33 & 8.00 & 7.50 & 6.90 & 7.68 & 12.03 & 11.33 & 9.50 & 6.67 & 9.88 \\
\hline $1 / 4$ & 3.00 & 3.20 & 2.70 & 2.60 & 2.88 & 3.60 & 3.40 & 3.40 & 2.90 & 3.33 \\
\hline mean & 6.18 & 5.90 & 5.47 & 5.00 & & 8.38 & 7.41 & 6.63 & 5.36 & \\
\hline \multicolumn{11}{|l|}{ LSD 0.05} \\
\hline MS strength & & & 0.48 & & & & & 0.65 & & \\
\hline Sucrose & & & 0.55 & & & & & 0.75 & & \\
\hline Interaction & & & $\mathrm{NS}^{*}$ & & & & & 1.29 & & \\
\hline
\end{tabular}

*NS denotes non-significant differences using ANOVA $(P<0.05)$.

Various concentrations of sucrose significantly influenced rooting of petunia microshoots. Lowering sucrose concertation favored rooting and promoted roots characteristics. The lowest concentration $(15 \mathrm{~g} / \mathrm{l})$ resulted in the highest rooting percentage $(81.10 \%)$, number of roots per shoot $(6.18)$ and the longest root $(8.38 \mathrm{~cm})$ comparing to the other sucrose concentrations. Rooting was negatively affected by the increase in sucrose concentration. The level of sucrose in the medium may have a direct effect on the type of morphogenesis. Previous reports have recorded inhibition in root formation as a result of excessive sugar concentration in the medium (Nhut et al., 2001 in Lilium longiflorum, Premkumar et al., 2003 in avocado) and the majority of investigations reported the impact of sucrose at 2\% (Premkumar et al., 2003, Tawfik, 1995). However, sucrose has been reported in the media for root formation at high concentrations (Tawfik et al., 2018). They stated that the medium with $\mathrm{pH}$ at 5.5 supplemented with $50 \mathrm{~g} / 1$ sucrose produced the highest significant value of rooting (85\%) and enhanced root formation in 7.5 days of Rosa spp. cv. Eiffel Tower.

The interaction between basal salt strength and sucrose concentration exhibited significant variation only in root length. Applying sucrose at the lowest concentration $(15 \mathrm{~g} / \mathrm{l})$ with full or $1 / 2$ MS produced the highest rooting percentage $(100 \%)$. The same sucrose concentration with $1 / 2$ 
MS induced the highest number of roots/shoot (8.33) and the longest roots $(12.03 \mathrm{~cm})$. These results were followed by $20 \mathrm{~g} / 1$ sucrose with $1 / 2$ MS strength. These results confirm previous findings reported by Harris and Stevenson (1979) on grapevine.. The benefit of low salt levels for root initiation may be due more to the need for a low nitrogen level, than for an increased osmotic potential (George et al., 2008).

\section{Acclimatization of in vitro raised plantlets}

High survival rate during the acclimatization stage is crucial for a successful micropropagation protocol. Selecting a proper growing medium helps achieving good results. Among the three mixtures of growing media tested in the current experiment, clay recorded the highest survival rate $(89 \%)$ and the longest shoots $(8.80 \mathrm{~cm})$ as shown in Table 9 and Fig 1-H. This was followed by the plantlets transferred to a mixture of equal parts from peatmoss, vermiculite and perlite recording $67 \%$ survival rate and $5.80 \mathrm{~cm}$ shoot length. When vermiculite was excluded from the previous mixture, the survival rate was significantly declined reaching $44.33 \%$, and shoot length reached $4.23 \mathrm{~cm}$. These results suggests the use of the low cost and readily available clay medium as a proper medium for acclimatization and field establishment of petunia plants (Fig 1- I) produced through micropropagation technique.

TABLE 9. Effect of growing medium on acclimatization of regenerated plantlets of Petunia hybrid after 4 weeks of transplanting.

\begin{tabular}{lcc} 
Growing & \multicolumn{2}{c}{ Parameters } \\
\cline { 2 - 3 } Media & Survival \% & Shoots length (cm) \\
\hline Clay & 89.00 & 8.80 \\
Peat moss + perlite (1:1) & 44.33 & 4.23 \\
Peat moss + vermiculite + perlite $(1: 1: 1)$ & 67.00 & 5.80 \\
\hline LSD 0.05 & 31.60 & 1.60 \\
\hline
\end{tabular}

\section{Conclusion}

Leaf explant culture of petunia hybrida from in vitro grown seedling were established. The best medium for callus induction was MS medium supplemented with $0.5 \mathrm{mg} / 1 \mathrm{BAP}$ plus $0.1 \mathrm{mg} / 1$ NAA. MS medium plus $0.2 \mathrm{mg} / \mathrm{l} \mathrm{BAP}$ induced the highest multiplication rate. Three passage of subculture gave the highest number of shoots. Full strength MS medium with $40 \mathrm{~g} / 1$ sucrose boosted multiplication performance. Highest rooting percentage was achieved on half strength MS medium with $15 \mathrm{~g} / 1$ sucrose. Rooted shoots showed the best survival when acclimatized on clay soil media with survival rate of $89 \%$.

Acknowledgments: The authors are grateful to employees and technicians at Department of Ornamental Plants, Faculty of Agriculture, Assiut University for technical assistance and their help throughout the course of the study.

Funding statements: The authors would like to extend their appreciation to the Higher Administration of Assiut University for funding part of this research work.
Conflicts of interest: The authors declare that they have no conflicts of interest related to the publication of this study

\section{$\underline{\text { References }}$}

Abu-Qaoud, H. (2012) Improving adventitious shoot regeneration from cultured leaf explants of Petunia hybrida using thidiazuron. African Journal of Biotechnology, 11, 11230-11235.

Abu-Qaoud, H., Abu-Rayya, A. and Yaish, S. (2010) In vitro regeneration and somaclonal variation of Petunia hybrida. Journal of Fruit and Ornamental Plant Research, 18, 71-81.

Aftab, F., Alam, M., Afrasiab, H. and Afrasiab, H. (2008) In vitro shoot multiplication and callus induction in gladiolus hybridus Hort. Pakistan Journal of Botany, 40, 517-522.

Burbulis, N., Blinstrubienė, A. and Jonytienė, V. (2015) In vitro regeneration from leaf explants of petunia hybrida L. Propagation of Ornamental Plants, 15, 47-52. 
Conner, A.J., Albert, N.W. and Deroles, S.C. (2009) Transformation and Regeneration of Petunia. In: Gerats T. and Strommer J. (Eds.) Petunia, Springer, New York, 395-409.

Corredoira, E., Ballester, A. and Vieitez, A.M. (2008) Thidiazuron-induced high-frequency plant regeneration from leaf explants of Paulownia tomentosa mature trees. Plant Cell, Tissue and Organ Culture, 95, 197-208.

de Paiva Neto, V.B. and Otoni, W.C. (2003) Carbon sources and their osmotic potential in plant tissue culture: does it matter? Scientia Horticulturae, 97, 193-202.

Deroles, S.C., Bradley, J.M., Davies, K.M. and Schwinn, K.E. (1996) Genetic transformation in Petunia. In: Bajaj, Y.P.S. (Ed.) Plant Protoplasts and Genetic Engineering VII, Springer-Verlag Berlin Heidelberg, 270-279.

Fan, X.F., Zhao, G.D. and Xu, J.Q. (2009) Study on callus induction and plant regeneration of Petunia hybrida. Northern Horticulture, 6.

Gao, H., Xia, X., An, L., Xin, X. and Liang, Y. (2017) Reversion of hyperhydricity in pink (Dianthus chinensis L.) plantlets by $\mathrm{AgNO} 3$ and its associated mechanism during in vitro culture. Plant Science, 254, $1-11$

George, E.F., Hall, M.A. and Klerk, G.-J.De. (2008) The Components of Plant Tissue Culture Media II: Organic Additions, Osmotic and $\mathrm{pH}$ Effects, and Support Systems. In George, E.F., Hall M.A. and Klerk G.D. (Eds.) Plant Propagation by Tissue Culture, Springer Dordrecht, Netherlands, 115-173.

Gomez, K.A. and Gomez, A.A. (1984) Statistical Procedures for Agricultural Research, $2^{\text {nd }}$ ed. JohnWily, NY., 680 p.

Grendysz, J., Jacek, J. and Danuta, D. (2017) Influence of micropropagation with addition of kinetin on development of a willow (Salix viminalis L.). World Scientific News, 70, 201-215.

Harris, R.E. and Stevenson, J.H. (1979) Virus elimination and rapid propagation of grapes in vitro. Combined Proceedings International Plant Propagators' Society, 29, 95-108.

Egypt. J. Hort. Vol. 46, No.1 (2019)
Huetteman, C.A. and Preece, J.E. (1993) Thidiazuron: a potent cytokinin for woody plant tissue culture. Plant Cell, Tissue and Organ Culture, 33, 105-119.

Jamshidnia, M. and Sayed Tabatabaei B.E. (2013) Callus induction and regeneration from shoot apex and leaf disc cultures of three commercial petunias. Advanced Crop Science, 3, 444-453.

Jin, X.L., Hu, Y. and Li, B.H. (2007) Establishment of a regeneration system from the stem of Petunia hybrida Vilm. Journal of Central South University of Forestry \& Technology, 5.

Kag, B., Hegde, V., Sathyanarayana, B.N., Sharath, R. and Manchali, S. (2018) Direct regeneration from leaf explants of petunia, Petunia hybrida. Research \& Reviews: Journal of Agricultural Science and Technology, 1, 33-38.

Kaviani, B. and Kazemi, D. (2017) Callus induction and organogenesis capacity from lamina explant of Petunia $\times$ hybrida F1 induced by BA and NAA. Journal of Ornamental Plants, 7, 157-162.

Meyer, L., Serek, M. and Winkelmann, T. (2009) Protoplast isolation and plant regeneration of different genotypes of Petunia and Calibrachoa. Plant Cell, Tissue and Organ Culture, 99, 27-34.

Mohamed, M.F., P.E. Read, and D.P. Coyne. (1992) Dark preconditioning, CPPU, and thidiazuron promote shoot organogenesis on seedling node explants of common and faba beans". Journal of the American Society for Horticultural Science, 117:668-672

Murashige, T. and Skoog, F. (1962) A revised medium for rapid growth and bioassays with tobacco tissue cultures. Physiologia Plantarum, 15, 473-497.

Murthy, B.N.S., Murch, S.J. and Saxena, P.K. (1998) Thidiazuron: a potent regulator of in vitro plant morphogenesis. In Vitro Cellular \& Developmental Biology - Plant, 34, 267-275.

Nhut, D.T., Van Le,B., Fukai, S., Tanaka, M. and Van, K.T.T. (2001) Effects of activated charcoal, explant size, explant position and sucrose concentration on plant and shoot regeneration of Lilium longiflorum via young stem culture. Plant Growth Regulation, 33, 59-65.

Pan, M.J.and Van Staden, J. (1999) Effect of activated charcoal, autoclaving and culture media on sucrose hydrolysis. Plant growth regulation, 29, 135-141. 
Premkumar, A., Barcelo-Munoz, A., Quesada, M.A., Mercado, J.A. and Pliego-Alfaro, F. (2003) Influence of sucrose concentration on in vitro rooting, growth, endogenous sugars and ex vitro survival of juvenile avocado. The Journal of Horticultural Science and Biotechnology, 78, 46-50.

Rani, D.N. and Nair, G.M. (2006) Effects of plant growth regulators on high frequency shoot multiplication and callus regeneration of an important Indian medicinal plant, nirgundi (Vitex negundo L.). In Vitro Cellular \& Developmental Biology - Plant, 42, 69-73.

Raquin, C. (1983) Utilization of different sugars as carbon source for in vitro anther culture of petunia. Zeitschrift Für Pflanzenphysiologie, 111, 453-457.

Rojas-Martinez, L.I., Visser, R.G.F. and Klerk, G.J.M.de. (2010) The hyperhydricity syndrome: waterlogging of plant tissues as a major cause. Propagation of Ornamental Plants, 10, 169-175.

Sanikhani, M., Frello, S. and Serek, M. (2006) TDZ induces shoot regeneration in various Kalanchoë blossfeldiana Poelln. cultivars in the absence of auxin. Plant Cell, Tissue and Organ Culture, 85, 75-82.

Schenk, N., Hsiao, K.C. and Bornman, C.H. (1991) Avoidance of precipitation and carbohydrate breakdown in autoclaved plant tissue culture media. Plant cell reports, 10, 115-119.

Skvirsky, R.C., Hanson, M.R. and Ausubel, F.M. (1984) Intraspecific genetic variation in cytokinincontrolled shoot morphogenesis from tissue explants of Petunia hybrida. Plant Science Letters, 35, 237-245.

Stehmann, J.R., Lorenz-Lemke, A.P., Freitas, L.B. and Semir, J. (2009) The genus Petunia. In: Gerats, T. and Strommer, J. (Eds.), Petunia, Springer, New York, 1-28.

Su-ping, Q. U. (2001) Tissue culture of colored common callalily (Petunia hybrida). Journal of Southwest Agricultural University, 5.

Tawfik A.A., Omer H.M., Essam Y.A. and Samar A.I. (2018) Optimizing micropropagation protocol for Rosa hybrida cv. Eiffel Tower with improved in vitro rooting ability. Egyptian Journal of Horticulture, 45, 323 -335.
Tawfik, A.A. (1995) In vitro propagation of Melaleuca armillaris. Assiut Journal of Agricultural Science, 26, 137-149.

Tawfik, A.A. and Noga, G. (2002) Cumin regeneration from seedling derived embryogenic callus in response to amended kinetin. Plant Cell, Tissue And Organ Culture, 69, 35-40.

Thirukkumaran, G., Ntui, V.O., Khan, R.S. and Mii, M. (2009) Thidiazuron: An efficient plant growth regulator for enhancing Agrobacterium-mediated transformation in Petunia hybrida. Plant Cell, Tissue and Organ Culture, 99, 109-115.

Uchida, H., Nakayachi, O., Otani, M., Kajikawa, M., Kohzu, Y., T. Yamato, K. and Ohyama, K. (2004) Plant regeneration from internode explants of Euphorbia tirucalli. Plant Biotechnology, 21, $397-$ 399.

Van Nieuwkerk, J.P., Zimmerman, R.H. and Fordham, I. (1986) Thidiazuron stimulation of apple shoot proliferation in vitro. HortScience, 21, 316-318.

Villamor, C.C. (2010) Influence of media strength and sources of nitrogen on micropropagation of ginger, Zingiber officinale Rosc. E-International Scientific Research Journal, 2, 150-155.

Whitehouse, A.B., Marks, T.R. and Edwards, G.A. (2002) Control of hyperhydricity in Eucalyptus axillary shoot cultures grown in liquid medium. Plant Cell, Tissue and Organ Culture, 71, 245-252.

Xian-Chun, Z.O. (2010) Effect of the plant hormone ratio on tissue culture of Petunia hybrida. Journal of Anhui Agricultural Science, 17.

Zimmerman, T.W. and Cobb, B.G. (1989) Vitrification and soluble carbohydrate levels in Petunia leaves as influenced by media gelrite and sucrose concentrations. Plant Cell Reports, 8, 358-360.

(Received 04/11/2018; accepted 07/12/2018) 


\section{تحسين التكثف غير المباشر والتضاعف العددى للأفرع الخضريه فى البيتونيا هيبريدا

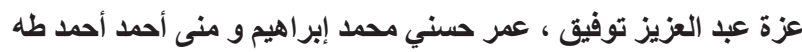

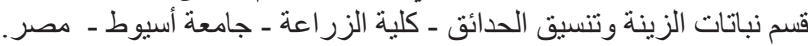

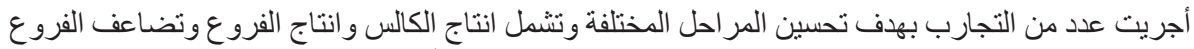

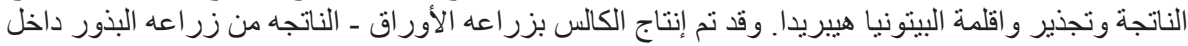

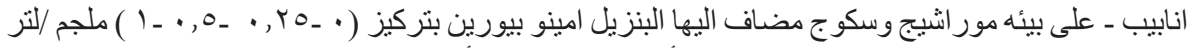

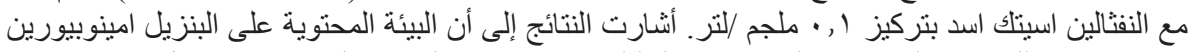

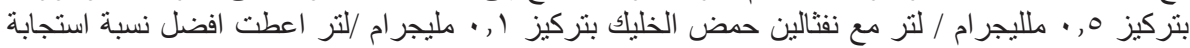

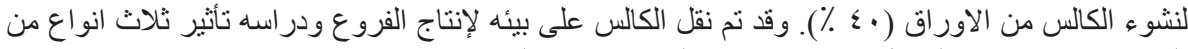

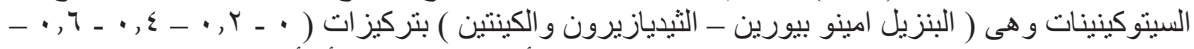

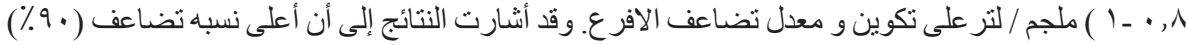

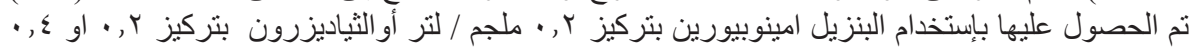

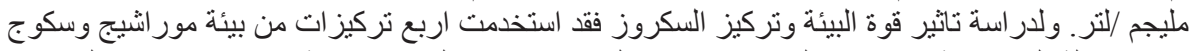

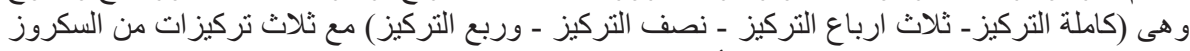

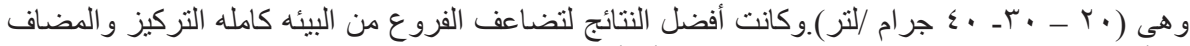

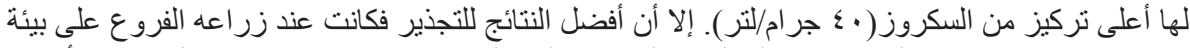

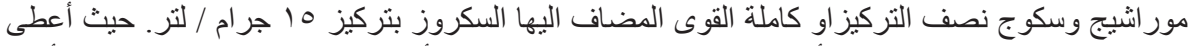

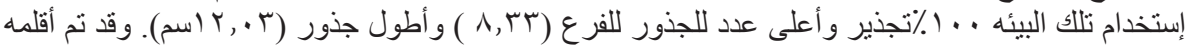

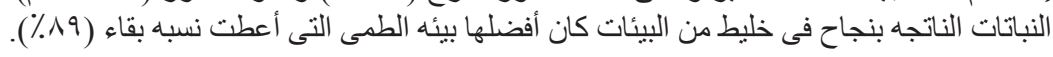

